第71回日本医科器械学会大会 インダストリフォーラム記録

インダストリーフォーラム

\section{2) アイシン精機(株)}

大動脈内バルーンパンピング B P 1

泉工医科工業(株)

(株)アイシンヒューマンシステムズ*

白江 博、藤吉孝次*

アイシン精機(株)では世界で初めて।AB $P$ の臨床使用を行ったカントロビッツ先生 の新しい発想を基に世界で初めてのフルオ ートモードを持つ। A B P 装置を開発しま した。取り扱い操作の簡便性と優れた不整 脈追従機能を有した、小型で低騒音の B P 1 を作り上げました。

スーパーバルーンポンプコラート B P 1 を 開発したアイシン精機（株）はトヨタ自動 車の最高級車であるセルシオを始め各車の 主要部品を製造している会社です。品質管 理の良いことで数回の表彰を受けるなど高 い品質管理と技術が医療機器の分野に生か されています。特にその機器の試験内容は 従来の」।S 規格の他にアイシン独自の品 質試験と付加耐久試験をクリアーし、ユー ザーの圧倒的な信頼を得ております。 スーパーバルーンポンプの開発は1968 年に世界で初めて急性心筋梗塞患者 3 例に
I A B P を使用し、その内 2 例に効果を確

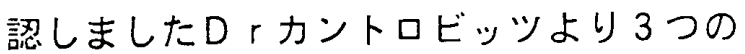
提案が出されました。

(1)駆動装置の調整を自動化にして取り扱 いに慣れないスタッフでも操作できる ようにすること。

(2)不整脈に対して完全自動追従すること。 (3)小型、低騒音であること。

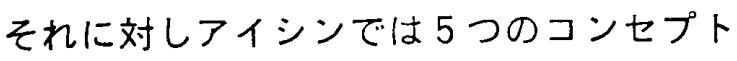
を基本に開発を行いました。

(1)スモール＆サイレント

幅 $31 \mathrm{~cm}$ 、奥行 $48 \mathrm{~cm}$ と世界で最も 小型であり騒音もルームクーラーと同等 の 54 ホーン以下におさえました。
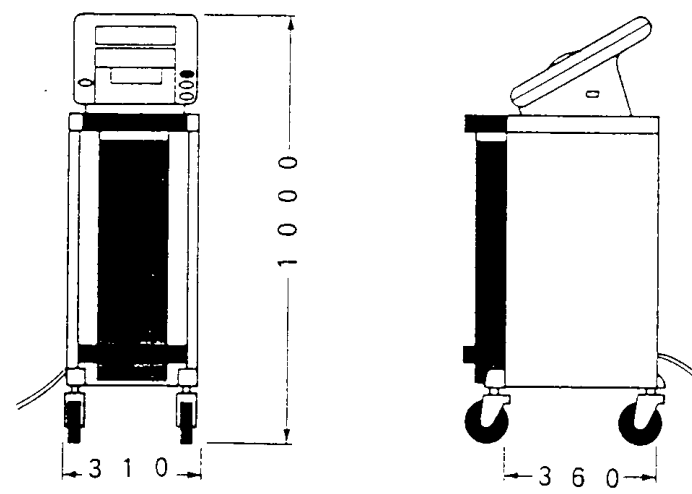

(2)シンプル

B P 1 は、操作スイッチを少なくするた めに自動化を行いマニュアルモードの他 にオートモードを実現しました。これは E C G と大動脈内の血圧を専用カテ先卜 ランスデューサにより検出しコンピュー タが自動的に駆動タイミングの調節をす 
るフルオート機能です。又マニュアルモ ードが今まで他社の|ABPで行ってい たオートモードに当たります。

(3)スピーディー

高速コンピュータにより波形のトリガと 電磁バルブへの信号を早く出すシステム を作り自動車用高速追従バルブと予任コ ントロール方式により高速圧力伝達を可 能にし194 B P Mでの臨床データも出 ております。

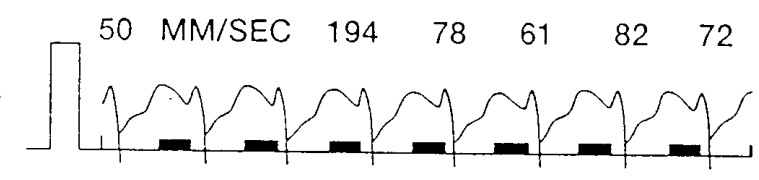

140

100

60

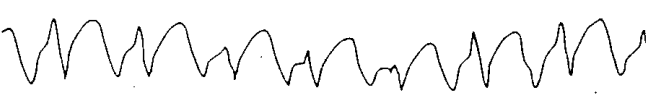

(4)セイフティー

新しいウイニング方法を考案しました。

これはオギュメンテーションを補助圧と 考え設定時間内で連続的にバルーンのボ リュームを下げ、補助圧力を下げて行く 方法です。安全のために患者血圧の低下 に対し警報をかけ、血栓の防止のために 2 分間に 3 拍フルボリュームで動きます。 もちろん今までと同じ間欠駆動によるウ イニング法も可能です。
(5)センシティブ

コラート B P 1 の優れた機能は専用バル ーンとカテ先トランスデューサの使用で 最高に生かされます。又患者まわりの配 線を少なくし安全をまもります。

まとめ

・| A B P に慣れないスタッフでも容易 に操作できます。

・不整脈に対する追従性が良く安定した 駆動ができます。

・新しいウイニング方法により安全なウ イニングができます。

・小型で騒音が少なく、患者まわりの環 境を守ります。

・尃用バルーンによりさらに安定した臨 床使用が可能です。

こうしたメリットのある「スーパーバルー ンポンプ コラートＢＰ１」は泉工医科工 業（株）がお手元にお届けします。

お問い合わせは 泉工医科工業株式会社 TEL $03-3812-3254$ FAX 03-3815-7011 